\title{
The Identification of the Response of Interest Rates to Monetary Policy Actions Using Market-Based Measures of Monetary Policy Shocks
}

\author{
Daniel L. Thornton \\ Federal Reserve Bank of St. Louis \\ Phone (314) 444-8582 \\ FAX (314) 444-8731 \\ E-mail Address: thornton@stls.frb.org
}

March 2011

\begin{abstract}
It has become common practice to estimate the response of asset prices to monetary policy actions using market-based measures as proxies for monetary policy shocks, such as the unexpected change in the federal funds futures rate. I show that because interest rates and market-based measures of monetary policy shocks respond simultaneously to all news and not simply news about monetary policy actions, estimates of the response of interest rates to monetary policy using such measures are biased. I propose a methodology that corrects for this "joint-response bias." The results indicate that when this bias is accounted for the response of Treasury yields to monetary policy actions is considerably weaker than previously estimated.
\end{abstract}

JEL Classification: E40, E52

Key words: monetary policy shocks, identification, simultaneity, federal funds target

The views expressed here are the author's and do not necessarily reflect the views of the Board of Governors of the Federal Reserve System or the Federal Reserve Bank of St. Louis. I thank Mike McCracken, Ken Kuttner, Ellen Meade, Lucio Sarno, Mark Watson, and Giorgio Valente for useful comments and Aditya Gummadavelli and Aaron Albert for helpful research assistance. 
Monetary policymakers and financial market participants are interested in knowing how market interest rates respond to Federal Reserve actions. Cook and Hahn (1989) were the first to estimate the response of Treasury yields to changes in the Fed's target for the federal funds rate. Specifically, they regressed daily changes in various Treasury yields on changes in the target and found that Treasury rates across the maturity spectrum responded strongly and significantly to changes in the federal funds rate target during the period 1973-79.

Using Cook and Hahn's event-study methodology for the period June 6, 1989, through February 2, 2000, Kuttner (2001) found a uniformly smaller response of Treasury rates to funds rate target changes. Noting that rates, especially longer-term rates, should only respond to unanticipated target changes, he suggested that the relative failure of Cook and Hahn's methodology in the latter period was likely a consequence of their failure to differentiate between expected and unexpected target changes.

Following Rudebusch's (1998) suggestion that federal funds futures rates provide a natural forecast of the Federal Open Market Committee's (FOMC's) target for the federal funds rate, Kuttner (2001) used the change in the federal funds futures rate on days when the funds rate target was changed as a proxy for the unexpected target change. Since then, it has become common practice to estimate the response of interest rates and other asset prices to unanticipated monetary policy actions using market-based measures of unexpected monetary policy actions - federal funds futures rates, eurodollar deposit rates, the 3-month T-bill rate, and eurodollar futures rates (e.g., Hamilton, 2008;

Gürkaynak, Sack, and Swanson, 2007; Faust, Swanson, and Wright, 2004; Bomfim, 
2003; Poole and Rasche, 2000; Poole, Rasche, and Thornton, 2002; and Cochrane and Piazzesi, 2002).

A number of researchers (e.g., Rigobon and Sack, 2004; Gürkaynak, Sack, and Swanson, 2005; and Craine and Martin, 2008) have recognized that if interest rates and the market-based measures of monetary policy shocks respond simultaneously to news from a variety of sources, and not only news about monetary policy actions, the estimated response of asset prices to monetary policy actions using market-based measures of monetary policy shocks will be biased and inconsistent. Rigobon and Sack (2004) note that the event study approach essentially assumes that essentially the only thing moving rates on days when there are policy actions is the surprise policy action. They propose to identify the effect of the policy action using a procedure called identification through heteroskedasticity. Specifically, they assume the variance of monetary policy shocks is larger on days when there are FOMC meetings and the Chairman's semi-annual testimony than on other days. The methodology purposed here corrects without making arbitrary assumptions about when the variance of monetary policy shocks is large. Specifically, it uses the market-based measure on all days as a latent variable to account for the relationship between assets prices and the market-based measure of monetary policy shocks on days when there are unexpected policy actions. The methodology permits one to identify the marginal effect of monetary surprises relative to nonmonetary shocks. The methodology is simple to employ and requires a simple identifying assumption. Moreover, it is easily modified to account for the effects of other events such as the market's reaction to other headline news. 
The results show that, when the joint-response bias is accounted for, the response of Treasury rates is considerably smaller than previously reported. For data prior to February 3, 2000, the marginal response of yields on Treasury securities with maturities of one year or less is about half of that obtained using the standard methodology, and those with maturities longer than a year there is no statistically significant response beyond the response to ambient news. For data after February 2, 2000, none of the Treasury rates respond significantly to unanticipated monetary policy actions.

The remainder of the paper is divided into five sections. Section 2 analyses the response of interest rates to news. Cook and Hahn's (1989) event-study methodology and Kuttner's critique and refinement of this methodology are presented in Section 3. Section 4 shows why market-based measures of monetary policy shocks yield biased estimates of the response of interest rates to monetary policy shocks. Section 5 presents a latentvariable methodology and compares the results using this and standard methodology. The conclusions are presented in Section 6.

\section{The Response of Interest Rates to News}

There have been any number of empirical investigations of the response of interest rates (or other assets prices) to headline news (e.g., Remolona and Fleming, 1999; Fleming and Remolona, 1999; and Bartolini, 2008). Because the FOMC has been targeting the federal funds rate, much of this research has focused on news about monetary policy (e.g., Gürkaynak et al., 2005; and Bernanke and Kuttner, 2005). Eventstudy research has focused on headline news events; however, interest rates and other asset prices respond to news from a wide variety of sources. Because this information is 
not easily identified, it is difficult if not impossible to associate a given response with a particular piece of news or event. I call such information ambient news.

This section analyzes the relationship between Kuttner's (2001) market-based monetary policy shock measure and changes in Treasury rates on all days, not only days when the funds rate target is changed. ${ }^{1}$ Kuttner's (2001) market-based monetary shock measure is primarily based on the spot, or current-month, federal funds futures rate. The federal funds futures rate is the rate on a derivative contract whose value depends on the average level of the effective federal funds rate in the month of the contract.

Consequently, the market's expectation for the average of the effective funds rate over the month on the $t^{\text {th }}$ day of the month is given by

$$
f f f_{t}^{0}=m^{-1}\left\{\left(\sum_{k=1}^{t-1} f f_{k}\right)(t-1)+\left(E_{t} \sum_{k=t}^{m} f f_{k}\right)(m-t+1)\right\},
$$

where $f f f_{t}^{0}$ denotes the rate on the current-month federal funds futures contract, $f f$ denotes the effective (overnight) federal funds rate, and $m$ denotes the number of days in the month. That is, the futures rate is simply a weighted average of the observed funds rate up to day $t$ and the market's expectation of the funds rate over the remainder of the month. If the market expects the FOMC to change its target on day $t$, but not again during the month, then $f f f_{t}^{0}-f f f_{t-1}^{0}$ would be zero. Hence, a natural way to estimate the monetary policy surprise is

$$
\Delta f f_{t}^{* u}=\frac{m}{m-t}\left(f f f_{t}^{0}-f f f_{t-1}^{0}\right) .
$$

\footnotetext{
${ }^{1}$ Piazzesi and Swanson (2008) argue that federal funds futures rate measures of financial markets' expectations of monetary policy may be biased because of a risk premium. They find, however, that Kuttner's (2001) measure appears to be relatively robust to risk premia in federal funds futures contracts, noting that "The difference-based measure may largely 'difference out' risk premia that are moving primarily at lower, business-cycle frequencies" (Piazzesi and Swanson, 2008, p. 690).
} 
Aware that this measure could not be calculated on the first day of the month, Kuttner replaced $f f f_{t-1}^{0}$ with the 1-month-ahead federal funds futures rate on the last day of the previous month. He also noted that there were problems with this measure on the last few days of the month, so he used

$$
\Delta f f_{t}^{* u}=\left(f f f_{t}^{1}-f f f_{t-1}^{1}\right)
$$

where $f f f_{t}^{1}$ denotes the rate on the 1-month-ahead federal funds futures contract on the last three days of the month. ${ }^{2}$

Kuttner (2001) calculated $\Delta f f_{t}^{* u}$ only for days when the FOMC changed its target for the funds rate and partitioned target changes into expected and unexpected target. Specifically,

$$
\Delta f f_{t}^{* e}=\Delta f f_{t}^{*}-\Delta f f_{t}^{* u}=\Delta f f_{t}^{*}-\frac{m}{m-t}\left(f f f_{t}^{0}-f f f_{t-1}^{0}\right),
$$

where $\Delta f f_{t}^{*}$ denotes the change in the funds rate target and $\Delta f f_{t}^{* e}$ denotes the expected target change. Note that $\Delta f f_{t}^{* u}$ can be calculated for any day of the month; however, the expected component of actual target changes can be calculated only on days when the target is changed.

Although the analysis presented here focuses on Kuttner's federal funds futures rate policy shock measure, it applies to all market-based measures of monetary policy shocks used in the literature.

\footnotetext{
${ }^{2}$ Poole and Rasche (2000) and Poole et al., (2002) used equation (3) exclusively as their measure of the monetary policy shock. The results presented here are qualitatively the same when Poole and Rasche's (2000) measure is used.
} 


\section{Estimating the Response of Interest Rates to Monetary Policy Actions}

Cook and Hahn (1989) estimated the response of Treasury rates to monetary policy actions by estimating the equation

$$
\Delta i_{t}=\alpha+\beta \Delta f f_{t}^{*}+\varepsilon_{t},
$$

where $f f_{t}^{*}$ denotes the FOMC's target for the federal funds rate and $i_{t}$ denotes one of several Treasury rates. ${ }^{3}$ They found that the estimate of $\beta$ was very close to 0.50 for the 3-, 6-, and 12-month T-bill rates, and that the estimates of $\beta$ then declined monotonically to 0.098 for the 20 -year bond yield as the term to maturity increased. Estimates of $\beta$ were highly statistically significant for all rates, and estimates of $\bar{R}^{2}$ ranged from 59 to 29 percent.

Kuttner (2001) estimated equation (1) over the period June 6, 1989, through February 2, 2000, and found that the reactions of interest rates to a change in the funds rate target were "uniformly smaller and less significant than those for the 1975-1979 sample period.” Moreover, there was no statistically significant response for long-term yields. Rejecting as "implausible" that this result could be due to market participants being unaware that the Fed was targeting the funds rate "because of the Fed's greater transparency," Kuttner (2001) suggested that "a more likely explanation is that target rate changes have been more widely anticipated in recent years." ${ }^{4}$ Specifically, he suggested that Cook and Hahn's (1989) event-study methodology failed to distinguish between anticipated and unanticipated target changes, which produced "noise" and resulted in "an

\footnotetext{
${ }^{3}$ Cook and Hahn (1989) did not use the actual change in the funds target because the magnitude and timing of these changes were unknown. Rather, they determined when the funds rate target had changed from press reports in the Wall Street Journal.

${ }^{4}$ Kuttner (2001, p. 526).
} 
attenuated estimate of interest rates' response to policy surprises." ${ }^{, 5} \mathrm{He}$ suggested that the bias could be eliminated by using the federal funds futures rate to proxy for the unexpected component of the target change. Specifically, he suggested that the response of interest rates to a monetary policy shock could be determined by estimating

$$
\Delta i_{t}=\alpha+\beta \Delta f f_{t}^{* u}+\omega_{t}
$$

on days when the FOMC changed its target for the funds rate.

\section{The Joint-Response of Treasury Rates and Kuttner Shocks}

It is easy to demonstrate that the estimate of the response to unexpected policy actions from equation (6) will be biased if the market-based measure responds to information other than monetary policy actions. Consequently, it is important to show that Kuttner's policy shock measure responds to news other than news about monetary policy actions. This is demonstrated in Table 1, which shows the correlations between Kuttner's measure and eight Treasury rates on days when there were no changes in the funds rate target. The sample period is June 6, 1989, through February 2, 2000, and the Treasury rates are the 3- and 6-month T-bill rates (tb3 and tb6) and the 1-, 3-, 5-, 7-, 10-, and 20-year Treasury bond yields ( $\mathrm{t} 1, \mathrm{t} 3, \mathrm{t} 5, \mathrm{t} 7, \mathrm{t} 10$, and $\mathrm{t} 20)$. The second column of Table 1 shows that Treasury rates and Kuttner shocks are strongly correlated on days when the funds rate target was not changed. Hence, Kuttner's shock measure responded to whatever the news moved Treasury rates on those days.

Because the federal funds futures rate reflects the market's expectation of the future monthly average effective funds rate, some might argue that the correlations on days when there is no target change merely reflect the market's expectation of future

\footnotetext{
${ }^{5}$ Kuttner (2001, p. 527).
} 
policy actions — not the joint response to ambient news. Indeed, under a strict funds rate targeting procedure the monthly the funds rate should equal the funds rate target on average over the month.

However, if the future rates only responded to actual or expected future policy actions, the correlations should be higher on days when there are relatively large Kuttner shocks because revisions of market participants' expectations about the FOMC's funds rate target should occur relatively infrequently and be associated with relatively large Kuttner shocks. This is not the case, however. Columns 3 through 6 of Table 1 present the correlations for subsamples based on the absolute magnitude of Kuttner shocks. The magnitude of the correlations is robust to the size of the shocks and are highly correlated even when $\left|\Delta f f_{t}^{* u}\right|$ is less than 2.5 basis points.

Some might suggest that because the FOMC was targeting the funds rate, the federal funds futures rate should only respond to surprise monetary policy actions. This suggestion ignores the fact that there was considerable uncertainty about the extent to which the FOMC was targeting the funds rate and the precise level of the funds rate target during much of the June 6, 1989 - February 2, 2000, sample period. This uncertainty diminished over time; however, as discussed below, the uncertainty was not completely resolved until February 2000. Thornton (2006a) shows that although the FOMC effectively returned to a funds rate operating procedure in September 1982, officially, the FOMC maintained it was targeting borrowed reserves. ${ }^{6}$ Indeed, until the mid-1990s, the FOMC remained ambiguous about the extent to which it was targeting the funds rate. For example, at the conclusion of its February 1994 meeting, when the FOMC

\footnotetext{
${ }^{6}$ See Thornton (2006a) for several reasons why the FOMC preferred to be seen as targeting borrowed reserves rather than the funds rate.
} 
began the practice of announcing policy actions, the funds rate was not mentioned. The statement read, "the Federal Open Market Committee decided to increase slightly the degree of pressure on reserve positions. The action is expected to be associated with a small increase in short-term money market interest rates." Prior to February 1994, market participants did not have complete knowledge of the extent to which the FOMC was using the federal funds rate as a policy instrument. Moreover, most target changes occurred between FOMC meetings and the market had to infer whether the FOMC had taken a policy action from signals that the Trading Desk of the Federal Reserve Bank of New York (hereafter, Desk) provided in conducting daily open market operations (e.g., Feinman, 1993). ${ }^{8}$.

Over time, the FOMC became increasingly open about the extent to which it was relying on the funds rate to implement monetary policy and about the level of the target. For example, when it reduced the funds rate target by 25 basis points in July 1995, the FOMC's statement read, "the Federal Open Market Committee decided to decrease slightly the degree of pressure on bank reserve positions...today's action will be reflected in a 25 basis point decline in the federal funds rate from about 6 percent to about 5-3/4 percent." ${ }^{9}$ The FOMC did not officially announce it was targeting the funds rate until December 21, 1999, when it announced that "The Federal Open Market Committee made no change today in its target for the federal funds rate." ${ }^{10}$ Ambiguity about the level of the target was not completely eliminated until the February 2, 2000, FOMC statement

\footnotetext{
${ }^{7}$ Board of Governors (1994), emphasis added.

${ }^{8}$ The classic case of misinterpreting the Desk's signal occurred the day before Thanksgiving 1989, when market analysts misinterpreted the Desk's action as a signal the Fed had eased policy.

${ }^{9}$ Board of Governors (1995), italics added.

${ }^{10}$ Board of Governors (1999), italics added.
} 
which read: "The Federal Open Market Committee voted today to raise its target for the federal funds rate by 25 basis points to 5-3/4 percent."11

Ambiguity about the funds rate target is reflected in the behavior of the funds rate relative to the target. Figure 1 presents the absolute daily difference between the funds rate and the funds rate target from September 6, 1989, through June 29, 2007. Daily differences of the funds rate from the target were very large prior to 2000 . The average absolute difference was 14 basis points before 2000 and only 5 basis points after.

The large daily differences of the funds rate from the target are also reflected in monthly average data presented in Figure 2. Prior to 2000 the monthly average difference was 5 basis points or larger for one-third of the months. In contrast, differences this large occurred for only 3.0 percent of the months from 2000 on. Given this uncertainty and the fact that the funds rate could deviate significantly from the FOMC's target, it is not difficult to understand why the federal funds futures rate might also respond to news that would affect interest rates more generally.

After 2000, the market not only knew the precise level of the FOMC's funds rate target, but Chairman Greenspan frequently signaled the magnitude of the next target change. Given the relatively small daily and monthly average differences between the funds rate and the target after 2000, it seems unlikely that Kuttner shocks on days when the target was unchanged would reflect information other than the market's expectation of a change in the target.

\footnotetext{
${ }^{11}$ Board of Governors (2000).
} 


\subsection{The Joint-Response Bias}

This section shows why the estimate of $\beta$ from equation (6) is biased when the market-based proxy for unexpected policy actions responds to ambient news. To see why, let $\Delta^{u} f f_{t}^{*}$ denote the unexpected target change, which is strictly unobservable, and $\Delta f f f$ denote the market-based proxy for the unexpected target change. Now assume that the market-based measure response to ambient news $\left(N_{t}\right)$ and the unexpected target change, i.e.,

$$
\Delta f f f_{t}=\lambda N_{t}+\delta \Delta^{u} f f_{t}^{*}+v_{t}
$$

where $\lambda$ and $\delta$ denote the response of the market-based measure to ambient news and unexpected target changes, respectively, and $v_{t}$ denotes an idiosyncratic shock to the market-based measure. Now assume that the interest rate of interest also responds to ambient news and unexpected target changes, i.e.,

$$
\Delta i_{t}=\mu N_{t}+\theta \Delta^{u} f f_{t}^{*}+\omega_{t}
$$

where $\mu$ and $\theta$ denote the response of the Treasury rate to ambient news and unexpected target changes, respectively, and $\omega_{t}$ denote idiosyncratic shock to the Treasury rate. Note that $\theta=\delta=0$ on days when the target is not change or if the Fed's action is fully anticipated.

Substituting equation (8) into equation (7) yields

$$
\Delta i_{t}=\alpha+\beta\left(\lambda N_{t}+\delta \Delta^{u} f f_{t}^{*}+v_{t}\right)+\varepsilon_{t} .
$$

It is easy to show that

$$
P \lim \hat{\beta}=\frac{\mu \lambda \sigma_{N}^{2}+\theta \delta \sigma_{\Delta^{u} f f^{*}}^{2}}{\lambda^{2} \sigma_{N}^{2}+\delta^{2} \sigma_{\Delta^{u} f f^{*}}^{2}},
$$


where $\sigma_{N}^{2}$ and $\sigma_{\Delta^{u} f f^{*}}^{2}$ denote the variance of ambient news and unexpected target changes, respectively. Equation (10) shows that the estimate of $\beta$ from equation (6) correctly identifies the response of the interest rate to an unexpected target change if and only if $\lambda=0$. If this were the case, $\Delta f f f_{t}=\delta \Delta^{u} f f_{t}^{*}+v_{t}$ so that response of the interest rate to an unexpected target change could be identified up to scalar, i.e., $P \lim \hat{\beta}=\theta / \delta$ - the relative response of the interest rate and the futures rate to an unexpected change in the funds rate target. If $\lambda \neq 0$; however, estimates of $\beta$ from equation (6) will be biased. ${ }^{12}$ Indeed, the estimate of $\beta$ could be nonzero even if the Fed's action was fully anticipated, i.e., $\theta=\delta=0$. Note that this bias arises because, while the ambient news shocks and unexpected monetary policy shocks are orthogonal, the response of the market-based policy measure at the daily frequency reflects the response to both shocks and not simply the monetary policy shocks.

\section{Correcting for the Joint-Response Bias}

Gürkaynak, Sack, and Swanson (2005) propose dealing with the joint-response bias by using data are measured over a time interval that is sufficiently short that it is "much less likely that any other significant events took place within this narrow window that might have influenced asset prices." ${ }^{\prime 13}$ Using extremely high-frequency data significantly reduces, if not eliminates, the joint-response bias; however, the estimated response using this data might overstate the effect of Fed actions on interest rates over the day. For example, Gürkaynak, Sack, and Swanson (2005) note that

\footnotetext{
${ }^{12}$ Estimates from equation (6) could also suffer from simultaneous equation bias. For example, for a period during the early 1990s the funds rate target was changed shortly after the Bureau of Labor Statistics released the employment report, igniting speculation that the FOMC was responding to the employment report.

${ }^{13}$ Gürkaynak, Sack, and Swanson (2007), p. 60.
} 
The Federal Reserve's announcement following its January 28, 2004, policy meeting led to one of the largest reactions in the Treasury market on record, with two- and five-year yields jumping 20 and 25 basis points (bp) respectively in the half-hour surrounding the announcement-the largest movements around any Federal Open Market Committee (FOMC) announcement over the fourteen years for which we have data.

Although the immediate reaction to this announcement was exceptional, the changes in these rates over the day were much less so. The daily changes in these rates were 17 and 15 basis points, respectively. Daily changes in other Treasury rates were smaller; for example, the 10- and 20-year yields changed by 11 and 10 basis points, respectively. These daily changes are not particularly unusual: On 267 days of the sample (6 percent) the 10-year Treasury yield changed by 11 basis points or more and on 135 days the 5 -year yield changed by 15 basis points or more. Consequently, using extremely high-frequency data may give a distorted picture of the extent to which interest rates respond to monetary policy shocks on the day. Moreover, most of the event-study literature has used daily data, which is more readily available.

Alternatively, Rigobon and Sack (2004) and Craine and Martin (2008) use a methodology that relies on the variance-covariance matrix to achieve structural identification in a simultaneous equation setting. However, the procedure relies on relatively strong assumptions about the relative variance of monetary policy shocks to other shocks. In contrast, the procedure described below only requires that all interest rates to news on all days regardless of whether there are monetary policy surprises or other headline news - an assumption that is easily verified.

The joint-response bias exists because interest rates and market-based monetary policy shock measures respond to all information relevant to interest rates. Hence, it is 
necessary to account for this bias in order to identify the effect of surprise monetary policy actions on interest rates. This can be done by using the market-based measure of a monetary policy shocks as a latent variable that accounts for the market's reaction to ambient news. Specifically, it can be achieved by estimating

$$
\Delta i_{t}=\alpha^{\prime}+\alpha^{\prime \prime}\left(T C_{t}\right)+\beta^{n} \Delta f f_{t}^{* u}+\beta^{m p s} \Delta f f_{t}^{* u}\left(T C_{t}\right)+\varepsilon_{t},
$$

where $\Delta f f_{t}^{* u}$ denotes Kuttner's market-based measure of unexpected target changes, $T C_{t}$ denotes a dummy variable that is 1.0 on days when the FOMC changed the funds rate target and zero otherwise, $\beta^{n}$ denotes the joint response of interest rates and marketbased measures of monetary policy shocks to ambient news, and $\beta^{m p s}$ denotes joint response of the interest rate and the market-based measure to unexpected target changes. Note that $\beta^{m p s}$ measures the marginal change in the interest rate associated with unexpected policy action. If $\beta^{m p s}$ is not significantly different from zero, the market's reaction to a surprise monetary policy action is no different from its reaction to ambient news - surprise monetary policy actions have no unique effect on interest rates. Note too that $\beta^{n}$ represents the size of the bias of the estimate of $\beta$ from equation (6), i.e., it is an estimate of the joint-response bias.

\subsection{The Response of Treasury Rates to Monetary Policy Shocks}

The initial investigation of the effect of the joint-response bias uses Kuttner's (2001) sample period, June 6, 1989 - February 2, 2000. A comparison of the sample sizes across the columns of Table 1 reveals that there are a small number of unusually large Kuttner shocks during the sample period. Specifically, there were 26 shocks that were 30 basis points or larger in absolute value; however, one of these occurred on a day when the 
target was changed. ${ }^{14}$ All but one of the remaining 25 unusually large shocks occurred early or late in the month, tended to be clustered, and were not associated with unusually large changes in Treasury rates (see Appendix B for details). These characteristic suggest that these unusually large Kuttner shocks are idiosyncratic to the federal funds futures market. Given these facts and the sensitivity of ordinary least squares estimates to extreme observations, these 25 unusually large Kuttner shocks were excluded from the sample. $^{15}$

The analysis begins by estimating Kuttner's (2001) equation,

$$
\Delta i_{t}=\alpha+\beta_{1} \Delta f f_{t}^{* u}+\beta_{2}\left(\Delta f f_{t}^{*}-\Delta f f_{t}^{* u}\right)+\varepsilon_{t},
$$

for each of eight Treasury rates. ${ }^{16}$ These estimates are reported in Table 2 . The table presents the parameter estimates, the corresponding p-values, as well as estimates of $\bar{R}^{2}$ and the standard error, SE. ${ }^{17}$ The estimates are similar to those reported by Kuttner (2001). None of the estimates of $\beta_{2}$ is statistically significant, indicating that anticipated policy actions are already reflected in rates. In contrast, all of the estimates of $\beta_{1}$ are positive and statistically significant, indicating that surprise monetary policy actions have a strong positive effect on interest rates across the term structure. The estimated response of the 3- and 6-month T-bill rates are much larger than those obtained by Cook and Hahn (1989) and the estimates decline monotonically as the term to maturity lengthens.

\footnotetext{
14 This occurred on July 2, 1992.

15 The qualitative conclusions are robust to whether these observations are included or excluded.

16 The Kuttner shocks on days when the funds rate target changed used here differ on a few occasions from those used by Kuttner (2001). The differences are twofold. First, the dates of target changes are from Thornton (2006a), and differ from Kuttner's on three days. There were also six days when the values are different, apparently because of differences in the futures rates used here and those used by Kuttner (2001). Appendix A shows the Kuttner shocks used here and Kuttner's (2001) shocks. In any event, these small differences are not important for the qualitative results presented here.

${ }^{17}$ The covariance matrix for this and all other equations reported in this paper were obtained using a heteroskedasticity and autocorrelation consistent estimator.
} 
The effect of the joint-response bias is investigated by estimating equation (11).

The estimates, presented in Table 3, show that sum of the estimates of $\beta^{n}$ and $\beta^{m p s}$ for each rate is somewhat smaller than the corresponding estimate of $\beta_{1}$ in Table 2; however,

the null hypothesis $\hat{\beta}^{n}+\hat{\beta}^{m p s}=\hat{\beta}_{1}$ cannot be rejected at any reasonable significance level for any of the eight rates. Consistent with the joint response to ambient news, estimates of $\beta^{n}$ are positive and highly statistically significant for all rates. In contrast, estimates of $\beta^{m p s}$ are statistically significant only for Treasuries with maturities of one year or less. For maturities beyond one year, there is no statistically significant effect of a surprise target change beyond the joint response to ambient news. Moreover, estimates of $\beta_{1}$ from equation (12) are statistically significantly larger than the corresponding estimates of $\beta^{m p s}$, reflecting the upward bias in estimates of policy shocks that can arise from using market-based measures of monetary policy shocks.

\subsection{Ambient News or Expectations of Future Target Changes?}

The analysis in Section 4 suggests several reasons why the relationship between the federal funds futures rate and Treasury rates on days when there not changes in the funds rate target is a consequence of the market's reaction to ambient news. Nevertheless, the possibility that this relationship reflects expectations of future target changes is investigated in two ways. First, several analysts (e.g., Rudebusch, 1998; Bernanke and Kuttner, 2005; and Gürkaynak et al., 2007) have suggested the possibility that the FOMC responded to the employment report. Moreover, there is evidence that the bond market responds to "headline" economic announcements (e.g., Fleming and 1999; and Balduzzi et al., 2001). Indeed, 17 of the 42 target changes during the sample period occurred on 
days when there where headline news announcements days (see Appendix C for a list of the headline news announcements used here). Consequently, market participants might be more inclined to revise their expectations of the likelihood of a future monetary policy action on headline-news-announcement days than on other days. If changes in the federal funds futures rate reflect changes in the market's expectation of future policy actions, the response of interest rates to Kuttner shocks should be larger on headline-newsannouncement days than on other days. This implication is investigated by estimating the equation,

$$
\Delta i_{t}=\alpha^{\prime}+\alpha^{\prime \prime}\left(T C_{t}\right)+\alpha^{\prime \prime \prime}(h l)+\beta^{n} \Delta f f_{t}^{* u}+\beta^{h l} \Delta f f_{t}^{* u}(h l)+\beta^{m p s} \Delta f f_{t}^{* u}\left(T C_{t}\right)+\varepsilon_{t},
$$

where $h l$ is a dummy variable that is equal to 1.0 on days when there is headline news announcement but no change in the funds rate target and zero on all other days. If the federal funds futures and Treasury rates are responding to expectations of future target changes, estimates of $\beta^{h}$ should be positive and statistically significant.

Estimates of Equation (13) are presented in Table 4. Only the estimates of $\beta^{n}$, $\beta^{h l}$, and $\beta^{m p s}$ are presented, along with the summary statistics. Estimates of $\beta^{h l}$ are positive for all eight interest rates; however, the estimates are not statistically significant at the short end of the yield curve, where the effect of a surprise target change is relatively large and statistically significant. Hence, it is difficult to interpret the statistically significant estimates of $\beta^{h l}$ for maturities of three years or longer as being caused by expectations of future target changes. Importantly, the estimates of $\beta^{m p s}$ differ only slightly from those reported in Table 3.

The second investigation is motivated by the FOMC's asymmetric policy directive. From 1983 through 1999 the FOMC's policy directive contained language 
widely thought to indicate the likelihood of a policy action before the next regularly scheduled FOMC meeting. ${ }^{18}$ The directive was said to be symmetric if the directive indicated that tightening or easing were equally likely in the future and asymmetric otherwise. Evidence indicates that intermeeting policy actions occurred more frequently and were somewhat larger under an asymmetric policy directive, (e.g., Thornton and Wheelock, 2000)

The symmetry of the FOMC's policy directive was known when the FOMC minutes where released. During this period the minutes were released about two to three weeks after the next FOMC meeting. Consequently, as a general rule, market participants did not know the symmetry of the policy directive that was operational at the time. However, Belongia and Kliesen (1994) document 11 occasions between early 1983 and May 1993 when information about the current policy directive was leaked in the press. Further analysis shows that on three of these occasions, the leak contained information about the asymmetry of the FOMC's policy directive. These leaks, reported in the Wall Street Journal, occurred on August 27, 1990, October 3, 1991, and May 24, 1993. Hence, from the date of the leak to the next meeting of the FOMC, market participants knew the asymmetry of the FOMC's policy directive.

To further investigate whether Kuttner shocks on days with no target changes might reflect market participants' expectations of future policy actions, the equation

$$
\Delta i_{t}=\alpha^{\prime}+\alpha^{\prime \prime}\left(T C_{t}\right)+\alpha^{\prime \prime \prime}(l k)+\beta^{n} \Delta f f_{t}^{*_{u}}+\beta^{l k} \Delta f f_{t}^{*_{u}}(l k)+\beta^{m p s} \Delta f f_{t}^{*_{u}}\left(T C_{t}\right)+\varepsilon_{t}
$$

\footnotetext{
${ }^{18}$ This directive was replaced by the "balance of risk" statement in January 2000. See Thornton and Wheelock (2000) for details.
} 
is estimated. $l k$ is a dummy variable that takes on the value 1.0 on days when the market knew the asymmetry of the FOMC's policy directive and zero otherwise. ${ }^{19}$

Estimates of equation (14) are present in Table 5. Estimates of $\beta^{l k}$ are negative for maturities of one year or less and positive for maturities of more than one year. However, the only estimate that is statistically significant is for the 3-month T-bill rate.

As with headline news, none of the estimates of $\beta^{m p s}$ is significantly different from those reported in Table 3. The results in Tables 4 and 5 are consistent with the idea that estimates of $\beta^{n}$ are the consequence of the joint-response of Treasury rates and the federal funds futures rate to ambient news, rather than the response to changing expectations of the FOMC's funds rate target.

\subsection{The Response to Monetary Shocks Since 2000}

By 2000 the FOMC funds target rate was well known. So too was the FOMC's practice of changing the target at regularly scheduled meetings, except in unusual circumstances and Chairman Greenspan's practice of frequently signaling target changes a few days in advance of the meeting. Consequently, there were fewer surprise target changes than during the prior sample period. This is reflected in the Kuttner shocks on days when the funds rate target was changed, which are presented in Table 6. With the exception of the three intermeeting target changes that occurred January 3, April 18, and September 17, of 2001, and November 6, 2002, when the market was expecting a 25basis-point reduction in the target rate and the FOMC reduced the target by 50 basis points, Kuttner shocks are relatively small. The lack of large Kuttner shocks is particularly pronounced after mid-2004: After May 2004 there are no Kuttner shocks

\footnotetext{
${ }^{19}$ Specifically, the dummy variable is one from the date of the leak to date of the next FOMC meeting.
} 
larger than 3 basis points in absolute value. In May 2004 the FOMC adopted the "measured pace" language in its press statement. This language was widely regarded as indicating that the FOMC would increase the funds rate target by 25 basis points at the next meeting. The FOMC fulfilled this expectation at each of the next 14 meetings. ${ }^{20}$ The language was modified at the December 2005 meeting and discontinued at the January 2006 meeting. There were three target changes after January 2006, all of which were signaled well in advance of the action.

It is also the case that there were 13 days when the absolute value of the shock was greater than or equal to 20 basis points on days when the target was not changed. As during the earlier sample period, these unusually large Kuttner shocks tended to occur toward the beginning or end of the month and were not generally associated with large changes in the Treasury rates. Moreover, six occurred after the $9 / 11$ terrorist attacks in September 2001 (see Appendix D for details). These 13 observations are excluded in the analyses presented below.

Estimates of Kuttner's equation (equation, 12) for the period February 3, 2000, through June 29, 2007, are presented in Table 7. The estimates of $\beta_{1}$ are much smaller than those reported in Table 2: Estimates of $\beta_{1}$ for Treasury rates with maturities from 3 months to 1 year are about half as large as those for the prior sample period. Moreover, estimates of the response of Treasury's with maturities longer than a year are statistically insignificant different from zero, suggesting that surprise policy actions had no significant effect on longer-term yields.

\footnotetext{
${ }^{20}$ See Thornton (2006b) for a discussion of the "measured pace" language.
} 
Estimates of equation (11) are presented in Table 8. All of the estimates of $\beta^{n}$ are positive and highly statistically significant, indicative of the joint response of Treasury rates and Kuttner shocks to ambient news. As before, estimates of the response of Treasury rates to monetary policy shocks from equation (12) are essentially the sum of $\beta^{n}$ and $\beta^{m p s}$ from equation (11). However, none of the estimates of $\beta^{m p s}$ is statistically significant at the 5 percent level except that for the 20 -year Treasury yield, which is negative. The negative estimate suggests that the 20 -year yield might reflect a revision of long-term inflation expectations.

The strong and statistically significant relationship between Kuttner shocks and changes in Treasury rates on days when there were no policy actions might be surprising given that the FOMC's funds rate target was well known and target changes principally occurred at FOMC meetings. These facts would seem to suggest that the federal funds futures rate should respond only to unexpected policy actions and not to ambient news. It is important to remember that while the daily and monthly average deviations of the federal funds rate from the funds rate target were significantly smaller after early 2000 , they were not zero (see Figures 1 and 2). Moreover, as noted in Table 1, the strength of the relationship between Kuttner shocks and changes in Treasury yields is essentially independent of the size of the Kuttner shock. Hence, ambient news could effects both the futures rate and Treasury rates in much the same way as during the prior period, even though the absolute value of the effects was small.

Nevertheless, knowledge of the FOMC's funds rate target and when the target was most likely to change appears to have affected the estimate of the response of Treasury rates to ambient news. Given the FOMC's targeting procedure, it is unlikely 
that market participants would revise their expectation of a target changes daily.

Consequently, the response of the federal funds futures rate to ambient news should be muted relative to the response of market rates. This is illustrated in Figure 3, which presents the distributions of Kuttner shocks, $\Delta t 1$ and $\Delta t 10$ for the sample periods June 6 , 1989 - February 2, 2000, and February 3, 2000 - June 29, 2007, on days with no target changes. The distribution of Kuttner shocks becomes significantly more leptokurtic during the most recent sample period and the standard deviation declines by more than 50 percent from the earlier period - from 0.0428 to 0.0184 . In contrast, the distributions of the 1- and 10-year bond yields are essentially unchanged: The standard deviation of the 1-year yield declines by about 20 percent while that of the 10-year yield declines by less than 1 percent. The muted response of the federal funds futures rate to ambient news results in larger estimates of $\beta^{n}$-the change in the Treasury rate per percentage point change in Kuttner shocks is larger.

\subsection{Ambient News or Expectations of Future Target Changes?}

The result that surprise policy actions had little or no effect on Treasury rates could also occur if target changes were anticipated. To investigate this possibility, equation (11) was estimated for the period February 3, 2000, through December 31, 2003, a period when relatively large monetary policy shocks were more numerous. The results (not presented here) are qualitatively the same as those presented in Tables 7 and 8 , suggesting that the result may not be due solely to the fact that policy actions were anticipated. Nevertheless, it is important to note that only 7 of the 16 monetary policy shocks during this sample period were 10 basis points or larger. Consequently, it is 
difficult to draw any firm conclusion about the extent to which the results over this period were affected by better expectations of funds rate target adjustments.

\section{Conclusion}

Following Kuttner's (2001) use of the federal funds futures rate to measure monetary policy shocks, it has become common to investigate the response of asset prices to unanticipated monetary policy actions using market-based measures of monetary policy shocks. This methodology is shown to yield biased estimates of the response of asset prices to monetary policy shocks when market-based measures of monetary policy shocks respond to news other than surprise monetary policy actions.

This bias can be accounted for by estimating the equation for all days in the sample and not merely days when there is a policy actions. In so doing, the market-based measure of monetary policy shocks is effectively a latent variable that accounts for the relationship between asset prices and the market-based measure of monetary policy shocks that arises because market prices and yields respond to the same information each day.

A comparison of the results using the latent-variable methodology with the standard methodology shows that the latter overestimates the response of Treasury yields to monetary policy shocks. For the sample period June 6, 1989, through February 2, 2000, the standard methodology yields estimates for bonds with maturities of 1 year or less that are about 40 to 50 percent too large. For maturities of 3 years and longer, the marginal response to monetary policy shocks is not statistically significant. For the February 3, 2000 - June 29, 2007, period the marginal response to monetary policy 
shocks is not statistically significant for any maturity except the 20-year Treasury yield, where the response is negative. 


\section{References}

Balduzzi, P., E. Elton, and C. Green. (2001) "Economic News and Bond Prices: Evidence from the U.S. Treasury Market," Journal of Financial and Quantitative Analysis, $36,523-543$.

Bartolini, L., L. Goldberg, and A. Sacarny. (2008) "How Economic News Moves Markets," Current Issues in Economics and Finance, Federal Reserve Bank of New York, 14(6), 1-7.

Belongia, M.T. and K.L. Kliesen. (1994) "Effects on Interest Rates of Immediately Releasing the FOMC Directives," Contemporary Economic Policy, 12, 79-91.

Bernanke, B.S. and K.N. Kuttner. (2005) "What Explains the Stock Market Reaction to Federal Reserve Policy?” Journal of Finance, 60, 1221-57.

Board of Governors of the Federal Reserve, Press Release, February 4, 1994.

Board of Governors of the Federal Reserve, Press Release, July 6, 1995.

Board of Governors of the Federal Reserve, Press Release, December 21, 1999.

Board of Governors of the Federal Reserve, Press Release, February 2, 2000.

Bomfim, A. (2003) "Pre-Announcement Effects, News Effects, and Volatility: Monetary Policy and the Stock Market," Journal of Banking and Finance, 27, 133-51.

Cochrane, J.H. and M. Piazzesi. (2002) “The Fed and Interest Rates: A High-Frequency Identification," American Economic Review, 92, 90-101.

Cook, T. and T. Hahn. (1989) "The Effect of Changes in the Federal Funds Rate Target on Market Interest Rates in the 1970s," Journal of Monetary Economics, 24(3), 331-51.

Craine, R. and V.L. Martin. (2008) "International Monetary Policy Surprise Spillovers," Journal of International Economics, 75, 180-196.

Faust, J., E.T. Swanson, and J.H. Wright. (2004) "Indentifying VARs Based on High Frequency Futures Data," Journal of Monetary Economics, 51, 1007-131.

Feinman, J.N. (1993) "Estimating the Open Market Desk's Daily Reaction Function," Journal of Money, Credit and Banking, 25, 231-47.

Fleming, M.J. and E.M. Remolona. (1999) "Price Formation and Liquidity in the U.S. Treasury Market: The Response to Public Information," Journal of Finance, 54(5), 1901-15. 
Gürkaynak, R.S., B.P. Sack, and E.T. Swanson. (2005) "Do Actions Speak Louder Than Words? The Response of Asset Prices to Monetary Policy Actions and Statements," International Journal of Central Banking, May, 55-93.

Gürkaynak, R.S., B.P. Sack, and E.T. Swanson. (2007) "Market-Based Measures of Monetary Policy Expectations," Journal of Business and Economic Statistics, 25, 201-12.

Hamilton, J.D. (2008) “Assessing Monetary Policy Effects Using Daily Federal Funds Futures Contracts,” Federal Reserve Bank of St. Louis Review, 90(4), 377-93.

Kuttner, K.N. (2001) "Monetary Policy Surprises and Interest Rates: Evidence from the Fed Funds Futures Market," Journal of Monetary Economics, 47(3), 523-44.

Piazzesi, M., and E.T. Swanson. (2008) "Futures Prices and Risk-Adjusted Forecasts of Monetary Policy," Journal of Monetary Economics, 55(4), 677-691.

Poole, W., R.H. Rasche. (2000) "Perfecting the Market's Knowledge of Monetary Policy," Journal of Financial Services Research, 18(2-3), 255-98.

Poole, W., R.H. Rasche, and D.L. Thornton. (2002) "Market Anticipations of Monetary Policy Actions," Federal Reserve Bank of St. Louis Review, 84(4), 65-94.

Remolona, E.M. and M.J. Fleming. (1999) "What Moves Bond Prices?" Journal of Portfolio Management, 25(4), 28-38.

Rigobon, R., and B.P. Sack. (2004) "The Impact of Monetary Policy on Asset Prices," Journal of Monetary Economics, 51, 1553-75.

Rudebusch, G.D. (1998) "Do Measures of Monetary Policy in a VAR Make Sense?" International Economic Review, 39, 907-31.

Thornton, D.L. (2006a) "When Did the FOMC Begin Targeting the Federal Funds Rate? What the Verbatim Transcripts Tell Us," Journal of Money, Credit and Banking, 38(8), 2039-71.

Thornton, D.L. (2006b) “"Measured Pace' in the Conduct of Monetary Policy,” Federal Reserve Bank of St. Louis Monetary Trends, June 2006.

Thornton, D.L. and D.C. Wheelock. (2000) "A History of the Asymmetric Policy Directive," Federal Reserve Bank of St. Louis Review, 82(5), 1-16.

Wallich, H.C. (1984) "Recent Techniques of Monetary Policy," Federal Reserve Bank of Kansas City Economic Review, 21-30. 


\begin{tabular}{|c|c|c|c|c|c|}
\hline & full sample & $\left|\Delta f f_{t}^{*} u\right|<30$ & $\left|\Delta f f_{t}^{* u}\right|<15$ & $\left|\Delta f f_{t}^{* u}\right|<5$ & $\left|\Delta f f_{t}^{* u}\right|<2.5$ \\
\hline$t b 3$ & 17.54 & 22.78 & 24.92 & 21.45 & 20.06 \\
\hline$t b 6$ & 19.57 & 26.24 & 28.92 & 24.92 & 21.56 \\
\hline$t 1$ & 20.62 & 27.04 & 30.13 & 26.46 & 22.74 \\
\hline$t 3$ & 16.83 & 22.07 & 25.34 & 21.53 & 18.63 \\
\hline$t 5$ & 14.66 & 19.20 & 22.84 & 19.68 & 17.29 \\
\hline$t 7$ & 13.80 & 17.80 & 21.33 & 17.98 & 16.73 \\
\hline$t 10$ & 13.20 & 17.01 & 20.42 & 17.91 & 16.53 \\
\hline$t 20$ & 11.13 & 14.59 & 17.77 & 16.22 & 15.00 \\
\hline No. of Obs. & 2626 & 2600 & 2542 & 2213 & 1787 \\
\hline
\end{tabular}

Table 2: Response to Monetary Policy Shocks (June 6, 1989 - February 2, 2000)

\begin{tabular}{|c||r|r||r|r||r|r||c|c|}
\hline \hline & $\alpha$ & $\mathrm{p}$-value & $\beta_{1}$ & $\mathrm{p}$-value & $\beta_{2}$ & $\mathrm{p}$-value & $\bar{R}^{2}$ & $\mathrm{SE}$ \\
\hline \hline$t b 3$ & -0.0001 & 0.9046 & 0.8749 & 0.0000 & -0.0322 & 0.6360 & 0.0979 & 0.0475 \\
\hline$t b 6$ & 0.0000 & 0.9766 & 0.8563 & 0.0000 & -0.0343 & 0.6080 & 0.0970 & 0.0467 \\
\hline$t 1$ & 0.0001 & 0.9427 & 0.8391 & 0.0000 & -0.0527 & 0.4214 & 0.0758 & 0.0517 \\
\hline$t 3$ & -0.0001 & 0.9326 & 0.5298 & 0.0000 & -0.0474 & 0.4424 & 0.0218 & 0.0611 \\
\hline$t 5$ & -0.0001 & 0.9087 & 0.4858 & 0.0000 & -0.0807 & 0.1824 & 0.0172 & 0.0617 \\
\hline$t 7$ & -0.0002 & 0.8385 & 0.3896 & 0.0000 & -0.0845 & 0.1710 & 0.0112 & 0.0605 \\
\hline$t 10$ & -0.0004 & 0.7485 & 0.3222 & 0.0001 & -0.0801 & 0.1521 & 0.0083 & 0.0577 \\
\hline$t 20$ & -0.0004 & 0.6883 & 0.2745 & 0.0006 & -0.0844 & 0.0950 & 0.0070 & 0.0537 \\
\hline
\end{tabular}

\begin{tabular}{|c||c|c||c|c|c|c|c|c|c||c|c|}
\hline \multicolumn{1}{|c|}{ Table 3: Joint-Response Bias Corrected Responses to Monetary Policy Shocks (June 6, 1989 - February 2, 2000) } \\
\hline \hline & $\alpha^{\prime}$ & $\mathrm{p}$-value & $\alpha^{\prime \prime}$ & $\mathrm{p}$-value & $\beta^{n}$ & $\mathrm{p}$-value & $\beta^{\text {mps }}$ & $\mathrm{p}$-value & $\bar{R}^{2}$ & SE \\
\hline \hline$t b 3$ & 0.0004 & 0.6465 & -0.0316 & 0.0022 & 0.2494 & 0.0000 & 0.5024 & 0.0000 & 0.1477 & 0.0462 \\
\hline$t b 6$ & 0.0007 & 0.4101 & -0.0338 & 0.0149 & 0.2788 & 0.0000 & 0.4464 & 0.0000 & 0.1611 & 0.0449 \\
\hline$t 1$ & 0.0008 & 0.4321 & -0.0277 & 0.0565 & 0.3223 & 0.0000 & 0.3953 & 0.0003 & 0.1433 & 0.0498 \\
\hline$t 3$ & 0.0005 & 0.6800 & -0.0191 & 0.2675 & 0.3130 & 0.0000 & 0.1273 & 0.3176 & 0.0687 & 0.0596 \\
\hline$t 5$ & 0.0004 & 0.7283 & -0.0190 & 0.2949 & 0.2751 & 0.0000 & 0.1020 & 0.4364 & 0.0522 & 0.0605 \\
\hline$t 7$ & 0.0003 & 0.8121 & -0.0209 & 0.2623 & 0.2512 & 0.0000 & 0.0210 & 0.8740 & 0.0418 & 0.0594 \\
\hline$t 10$ & 0.0001 & 0.9335 & -0.0165 & 0.3319 & 0.2288 & 0.0000 & -0.0068 & 0.9554 & 0.0357 & 0.0568 \\
\hline$t 20$ & 0.0000 & 0.9643 & -0.0190 & 0.2085 & 0.1839 & 0.0000 & -0.0205 & 0.8563 & 0.0273 & 0.0531 \\
\hline
\end{tabular}




\begin{tabular}{|c||c|c|c|c||c|c||c|c|}
\hline \multicolumn{2}{|c|}{ Table 4: Estimates of Equation (13) (June 6, 1989 - February 2, 2000) } \\
\hline & $\beta^{n}$ & $\mathrm{p}$-value & $\beta^{h}$ & $\mathrm{p}$-value & $\beta^{m p s}$ & $\mathrm{p}$-value & $\bar{R}^{2}$ & SE \\
\hline \hline$t b 3$ & 0.2457 & 0.0000 & 0.0102 & 0.8741 & 0.5043 & 0.0000 & 0.1518 & 0.0461 \\
\hline$t b 6$ & 0.2658 & 0.0000 & 0.0402 & 0.5239 & 0.4433 & 0.0000 & 0.1622 & 0.0449 \\
\hline$t 1$ & 0.2849 & 0.0000 & 0.1165 & 0.0827 & 0.3832 & 0.0005 & 0.1464 & 0.0497 \\
\hline$t 3$ & 0.2607 & 0.0000 & 0.1635 & 0.0217 & 0.1092 & 0.4118 & 0.0722 & 0.0595 \\
\hline$t 5$ & 0.2234 & 0.0000 & 0.1615 & 0.0223 & 0.0842 & 0.5295 & 0.0557 & 0.0604 \\
\hline$t 7$ & 0.2066 & 0.0000 & 0.1393 & 0.0341 & 0.0056 & 0.9671 & 0.0443 & 0.0593 \\
\hline$t 10$ & 0.1867 & 0.0000 & 0.1316 & 0.0350 & -0.0216 & 0.8634 & 0.0380 & 0.0568 \\
\hline$t 20$ & 0.1472 & 0.0000 & 0.1148 & 0.0528 & -0.0332 & 0.7766 & 0.0294 & 0.0530 \\
\hline
\end{tabular}

\begin{tabular}{|c||c|c|c|c|c|c||c|c|}
\hline \multicolumn{2}{|c|}{ Table 5: Estimates of Equation (14) (June 6, 1989 - February 2, 2000) } \\
\hline \hline & $\beta^{n}$ & $\mathrm{p}$-value & $\beta^{l k}$ & $\mathrm{p}$-value & $\beta^{m p s}$ & $\mathrm{p}$-value & $\bar{R}^{2}$ & SE \\
\hline \hline$t b 3$ & 0.2597 & 0.0000 & -0.1692 & 0.0428 & 0.4921 & 0.0000 & 0.1489 & 0.0461 \\
\hline$t b 6$ & 0.2856 & 0.0000 & -0.1021 & 0.2867 & 0.4397 & 0.0000 & 0.1620 & 0.0449 \\
\hline$t 1$ & 0.3248 & 0.0000 & -0.0213 & 0.8420 & 0.3931 & 0.0004 & 0.1438 & 0.0498 \\
\hline$t 3$ & 0.3127 & 0.0000 & 0.0327 & 0.8054 & 0.1280 & 0.3167 & 0.0691 & 0.0596 \\
\hline$t 5$ & 0.2743 & 0.0000 & 0.0420 & 0.7556 & 0.1033 & 0.4324 & 0.0525 & 0.0605 \\
\hline$t 7$ & 0.2518 & 0.0000 & 0.0130 & 0.9174 & 0.0208 & 0.8758 & 0.0419 & 0.0594 \\
\hline$t 10$ & 0.2291 & 0.0000 & 0.0147 & 0.9083 & -0.0068 & 0.9555 & 0.0357 & 0.0568 \\
\hline$t 20$ & 0.1824 & 0.0000 & 0.0457 & 0.7104 & -0.0187 & 0.8697 & 0.0273 & 0.0531 \\
\hline
\end{tabular}




\begin{tabular}{|c|c|c|c|}
\hline \multicolumn{4}{|c|}{$\begin{array}{l}\text { Table 6: Kuttner Shocks on Days When the Target Changed (February 3, } 2000 \text { - } \\
\text { June 29, 2007) }\end{array}$} \\
\hline Date & Kuttner Shock & Date & Kuttner Shock \\
\hline $3 / 21 / 2000$ & -3 & $8 / 10 / 2004$ & 1 \\
\hline $5 / 16 / 2000$ & 4 & $9 / 21 / 2004$ & 3 \\
\hline $1 / 3 / 2001$ & -38 & $11 / 10 / 2004$ & 0 \\
\hline $1 / 31 / 2001$ & 0 & $12 / 14 / 2004$ & 0 \\
\hline $3 / 20 / 2001$ & 6 & $2 / 2 / 2005$ & 0 \\
\hline $4 / 18 / 2001$ & -43 & $3 / 22 / 2005$ & 0 \\
\hline $5 / 15 / 2001$ & -8 & $5 / 3 / 2005$ & 0 \\
\hline $6 / 27 / 2001$ & 10 & $6 / 30 / 2005$ & 0 \\
\hline $8 / 21 / 2001$ & 3 & $8 / 9 / 2005$ & 0 \\
\hline 9/17/2001 & -32 & $9 / 20 / 2005$ & 1 \\
\hline $10 / 2 / 2001$ & -6 & $11 / 1 / 2005$ & 0 \\
\hline $11 / 6 / 2001$ & -10 & $12 / 12 / 2005$ & 0 \\
\hline $12 / 11 / 2001$ & 0 & $1 / 31 / 2006$ & 0 \\
\hline $11 / 6 / 2002$ & -19 & $3 / 28 / 2006$ & 0 \\
\hline $6 / 25 / 2003$ & 12 & $5 / 10 / 2006$ & -1 \\
\hline $6 / 30 / 2004$ & -1 & $6 / 29 / 2006$ & -2 \\
\hline
\end{tabular}

\begin{tabular}{|c|c|c||c|c|c|c|c|c|}
\hline \multicolumn{6}{|c|}{ Table 7: Response to Monetary Policy Shocks (February 3, 2000 - June 29, 2007) } \\
\hline & $\alpha$ & $\mathrm{p}$-value & $\beta_{1}$ & $\mathrm{p}$-value & $\beta_{2}$ & $\mathrm{p}$-value & $\bar{R}^{2}$ & SE \\
\hline \hline$t b 3$ & 0.0002 & 0.8301 & 0.4742 & 0.0000 & 0.0379 & 0.1650 & 0.0455 & 0.0376 \\
\hline$t b 6$ & 0.0000 & 0.9519 & 0.4204 & 0.0000 & 0.0522 & 0.0884 & 0.0483 & 0.0336 \\
\hline$t 1$ & -0.0003 & 0.7591 & 0.2886 & 0.0033 & 0.0240 & 0.4363 & 0.0136 & 0.0416 \\
\hline$t 3$ & -0.0008 & 0.5947 & 0.0012 & 0.9944 & 0.0525 & 0.1826 & 0.0001 & 0.0615 \\
\hline$t 5$ & -0.0008 & 0.5611 & -0.0231 & 0.8983 & 0.0390 & 0.3146 & 0.0000 & 0.0618 \\
\hline$t 7$ & -0.0010 & 0.4865 & -0.0840 & 0.6431 & 0.0044 & 0.8982 & 0.0000 & 0.0605 \\
\hline$t 10$ & -0.0009 & 0.4842 & -0.1197 & 0.4767 & -0.0019 & 0.9454 & 0.0002 & 0.0570 \\
\hline$t 20$ & -0.0009 & 0.4361 & -0.1244 & 0.2321 & -0.0166 & 0.4871 & 0.0009 & 0.0514 \\
\hline
\end{tabular}




\begin{tabular}{|c||c|c|c|c|c|c|c|c|c||c|c|}
\hline \multicolumn{1}{|c|}{ Table 8: The Appropriately Identified Response to Monetary Policy Shocks (February 3, 2000 - June 29, 2007) } \\
\hline \hline & $\alpha$ & $\mathrm{p}$-value & $\alpha^{\prime \prime}$ & $\mathrm{p}$-value & $\beta^{n}$ & $\mathrm{p}$-value & $\beta^{m p s}$ & $\mathrm{p}$-value & $\bar{R}^{2}$ & SE \\
\hline \hline$t b 3$ & 0.0002 & 0.7945 & -0.0191 & 0.0039 & 0.4391 & 0.0035 & 0.0045 & 0.9795 & 0.0908 & 0.0367 \\
\hline$t b 6$ & 0.0000 & 0.9784 & -0.0192 & 0.0165 & 0.4047 & 0.0000 & -0.0096 & 0.9412 & 0.0952 & 0.0327 \\
\hline$t 1$ & -0.0005 & 0.5893 & -0.0029 & 0.7462 & 0.4325 & 0.0003 & -0.1424 & 0.3806 & 0.0482 & 0.0409 \\
\hline$t 3$ & -0.0011 & 0.4467 & 0.0068 & 0.5887 & 0.3756 & 0.0045 & -0.3398 & 0.1429 & 0.0110 & 0.0612 \\
\hline$t 5$ & -0.0011 & 0.4558 & 0.0025 & 0.8346 & 0.3410 & 0.0065 & -0.3443 & 0.1623 & 0.0085 & 0.0616 \\
\hline$t 7$ & -0.0012 & 0.3967 & 0.0006 & 0.9524 & 0.3094 & 0.0084 & -0.3908 & 0.1066 & 0.0076 & 0.0605 \\
\hline$t 10$ & -0.0011 & 0.4036 & -0.0003 & 0.9700 & 0.2795 & 0.0094 & -0.4011 & 0.0762 & 0.0076 & 0.0568 \\
\hline$t 20$ & -0.0010 & 0.4020 & -0.0050 & 0.5149 & 0.2074 & 0.0148 & -0.3497 & 0.0194 & 0.0058 & 0.0512 \\
\hline
\end{tabular}


Figure 1: Difference Between the Federal Funds Rate and the FOMC's Funds Rate Target

(June 6, 1989 - June 29, 2007)

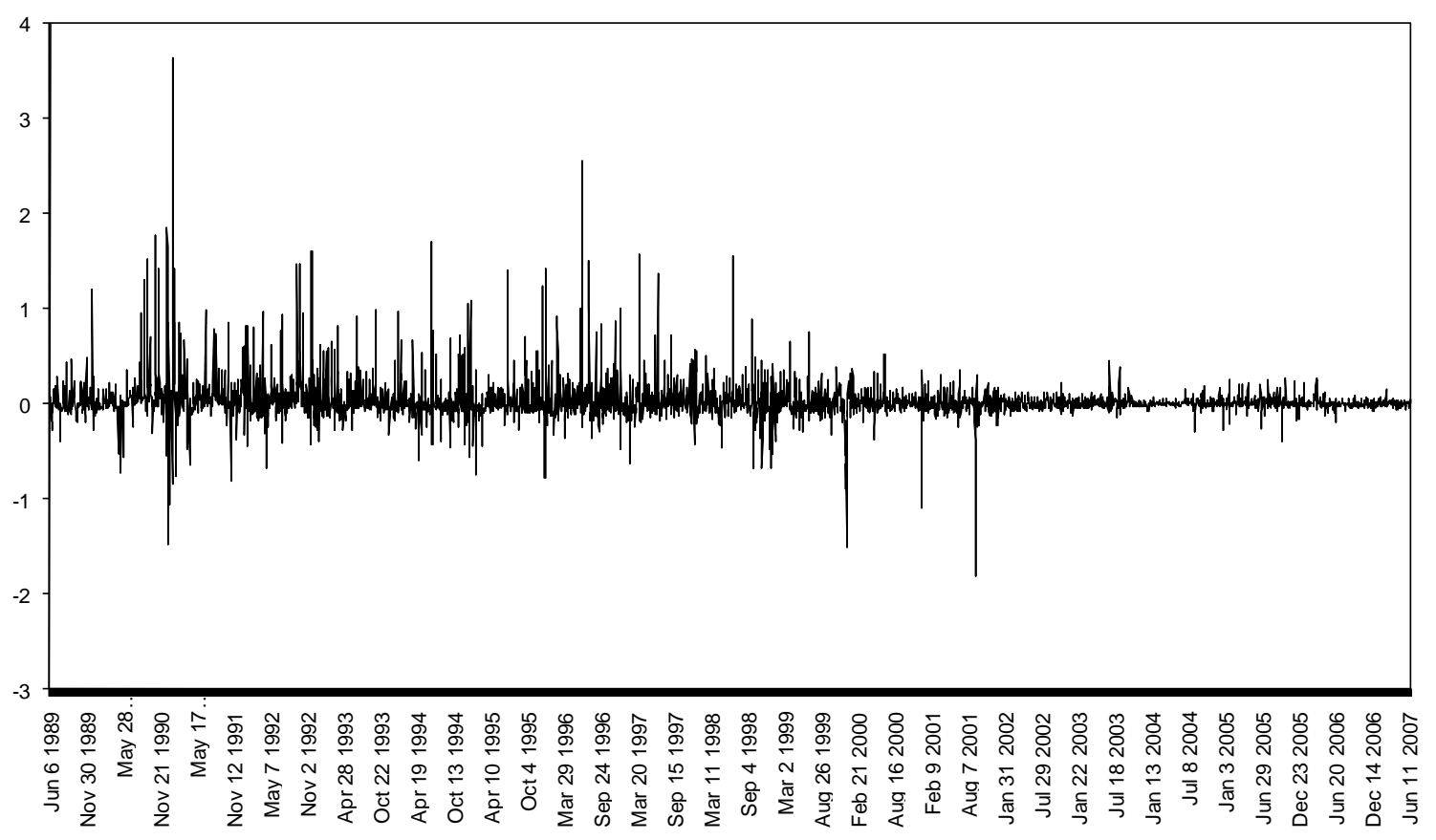




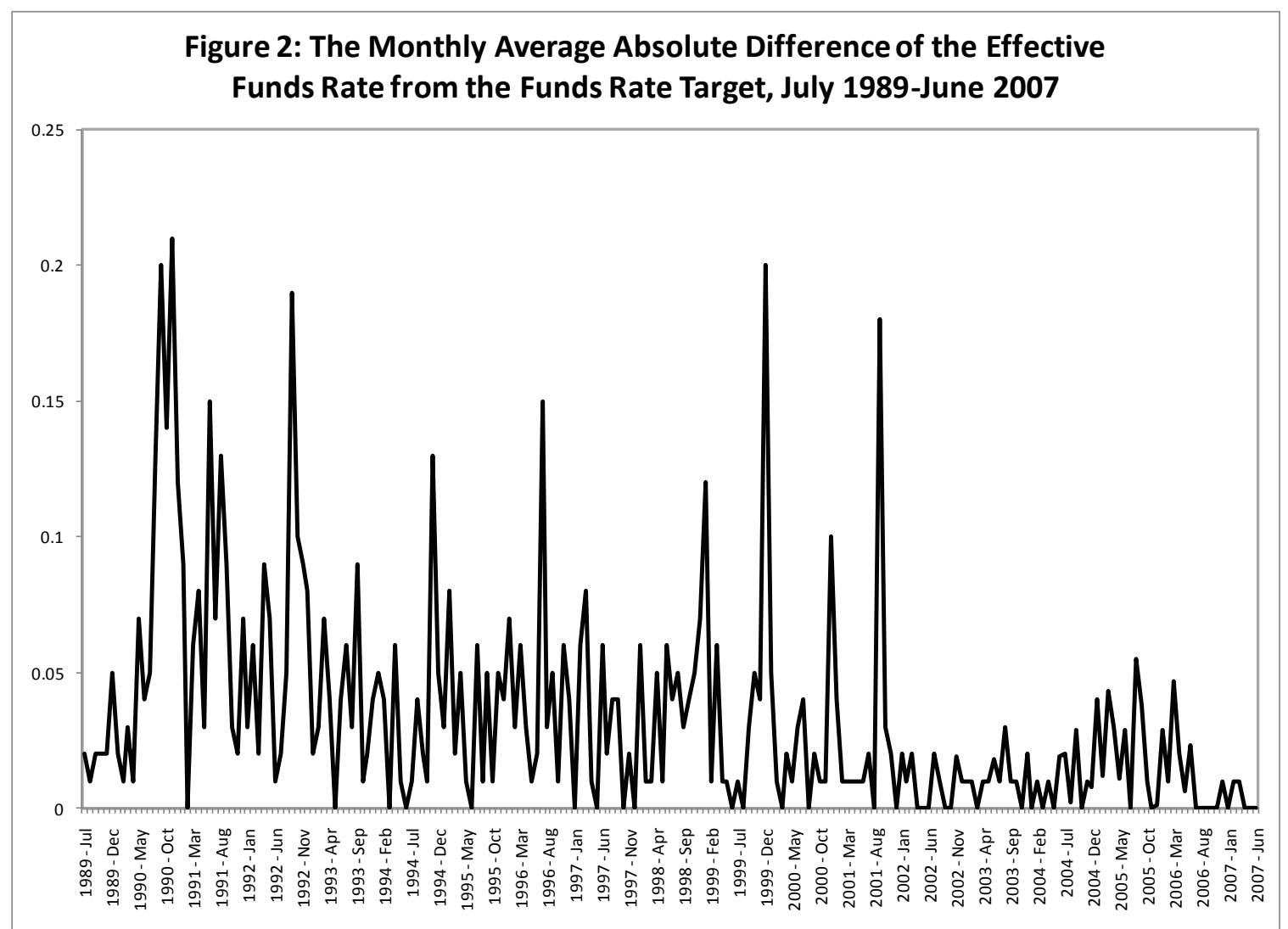


Figure 3: Densities for June 6, 1989 - February 2, 2000 and February 3, 2000 - June 29, 2007 Sample Periods, Solid and Dashed Lines, Respectively

$\Delta f f_{t}^{* u}$

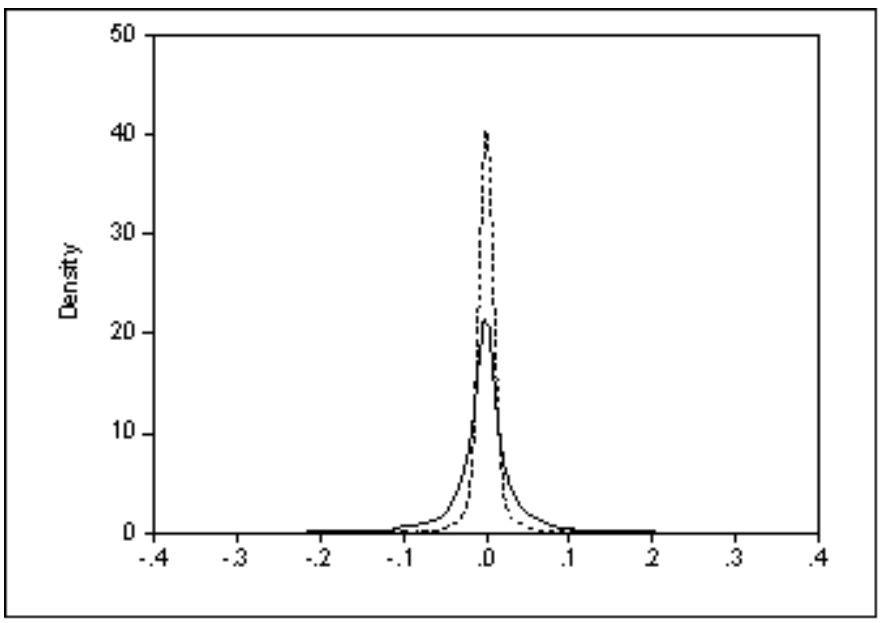

$\Delta T 1$

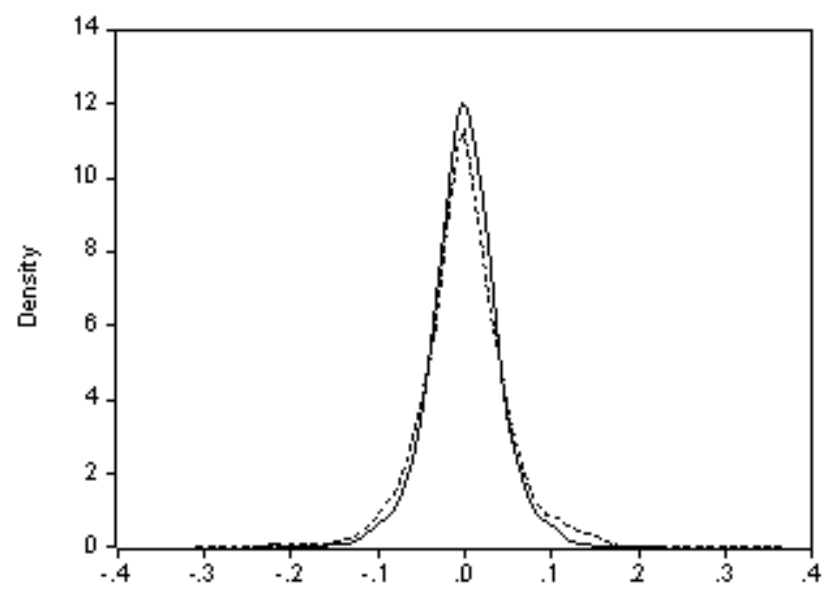

$\Delta T 10$

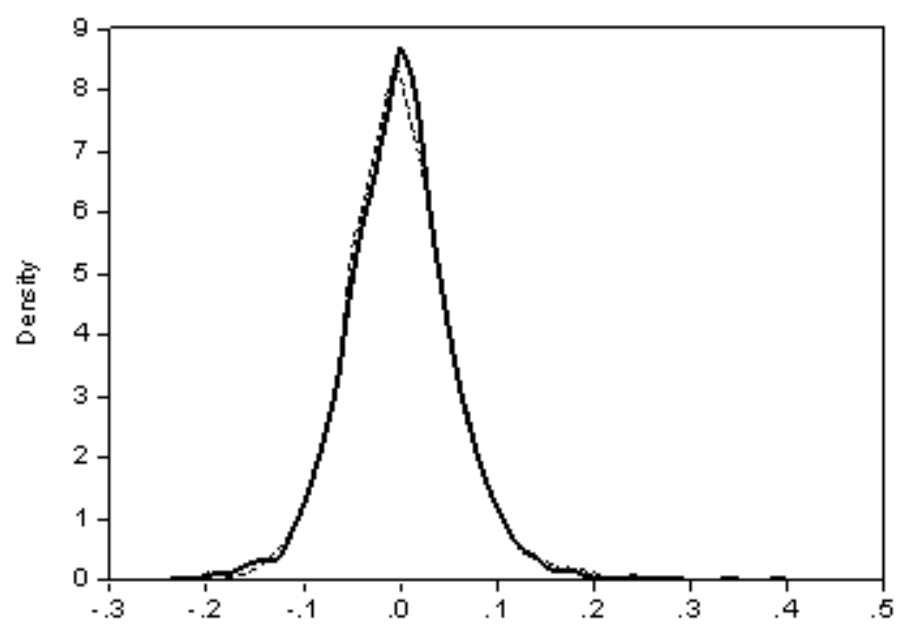




\begin{tabular}{|c|c|c||c|c|c|}
\hline \multicolumn{7}{|c|}{ Appendix A: Kuttner Shocks Used Here and Kuttner's Shocks for Kuttner's Sample Period } \\
\hline \hline Date & Kuttner shock & Kuttner's shock & Date & Kuttner shock & Kuttner's shock \\
\hline \hline $6 / 6 / 1989$ & -0.01 & -0.01 & $12 / 20 / 1991$ & -0.28 & -0.28 \\
\hline $7 / 7 / 1989$ & -0.03 & -0.03 & $4 / 9 / 1992$ & -0.24 & -0.24 \\
\hline $7 / 27 / 1989$ & 0 & 0 & $7 / 2 / 1992$ & -0.36 & -0.36 \\
\hline $10 / 16 / 1989$ & -0.21 & na & $9 / 4 / 1992$ & -0.22 & -0.22 \\
\hline $10 / 18 / 1989$ & na & 0 & $2 / 4 / 1994$ & 0.12 & 0.12 \\
\hline $11 / 6 / 1989$ & 0.04 & 0.04 & $3 / 22 / 1994$ & -0.03 & -0.03 \\
\hline $12 / 20 / 1989$ & -0.17 & -0.17 & $4 / 18 / 1994$ & 0.1 & 0.1 \\
\hline $7 / 13 / 1990$ & -0.14 & -0.14 & $5 / 17 / 1994$ & 0.13 & 0.13 \\
\hline $10 / 29 / 1990$ & -0.02 & -0.31 & $8 / 16 / 1994$ & 0.14 & 0.14 \\
\hline $11 / 14 / 1990$ & 0.04 & 0.04 & $11 / 15 / 1994$ & 0.14 & 0.14 \\
\hline $12 / 7 / 1990$ & -0.27 & -0.27 & $2 / 1 / 1995$ & 0.05 & 0.05 \\
\hline $12 / 18 / 1990$ & na & -0.21 & $7 / 6 / 1995$ & -0.01 & -0.01 \\
\hline $12 / 19 / 1990$ & -0.23 & na & $12 / 19 / 1995$ & -0.1 & -0.1 \\
\hline $1 / 8 / 1991$ & na & -0.18 & $1 / 31 / 1996$ & -0.07 & -0.07 \\
\hline $1 / 9 / 1991$ & -0.13 & na & $3 / 25 / 1997$ & 0.03 & 0.03 \\
\hline $2 / 1 / 1991$ & -0.26 & -0.25 & $9 / 29 / 1998$ & 0.06 & 0 \\
\hline $3 / 8 / 1991$ & -0.16 & -0.16 & $10 / 16 / 1998$ & -0.217 & -0.26 \\
\hline $4 / 30 / 1991$ & -0.17 & -0.17 & $11 / 17 / 1998$ & -0.06 & -0.06 \\
\hline $8 / 6 / 1991$ & -0.15 & -0.15 & $6 / 30 / 1999$ & -0.04 & -0.04 \\
\hline $9 / 13 / 1991$ & -0.05 & -0.05 & $8 / 24 / 1999$ & 0 & 0.02 \\
\hline $10 / 31 / 1991$ & -0.05 & -0.05 & $11 / 16 / 1999$ & 0.09 & 0.09 \\
\hline $11 / 6 / 1991$ & -0.13 & -0.12 & $2 / 2 / 2000$ & -0.05 & -0.05 \\
\hline $12 / 6 / 1991$ & -0.09 & -0.09 & & & \\
\hline & & & & & \\
\hline
\end{tabular}




\begin{tabular}{|c|c|c|c|c|c|c|c|c|c|}
\hline \multicolumn{10}{|c|}{$\begin{array}{l}\text { Appendix B: Kuttner Shocks and Changes in Treasury Rates on Days When There Are } \\
\text { Unusually Large Kuttner Shocks and No Target Change (basis points) }\end{array}$} \\
\hline Date & K-shock & $t b 3$ & $t b 6$ & $t 1$ & t3 & $t 5$ & $t 7$ & $t 10$ & $t 20$ \\
\hline $12 / 27 / 1989$ & 47 & -3 & -4 & -1 & 1 & -1 & -3 & -1 & -2 \\
\hline $12 / 28 / 1989$ & 41 & -5 & -4 & -5 & -4 & -4 & -3 & -3 & -2 \\
\hline $1 / 2 / 1990$ & -31 & 3 & 2 & 5 & 3 & 1 & 1 & 1 & 1 \\
\hline $9 / 24 / 1990$ & 30 & 3 & 4 & 6 & 7 & 6 & 5 & 5 & 5 \\
\hline $9 / 27 / 1990$ & -40 & -10 & -13 & -12 & -10 & -11 & -9 & -9 & -9 \\
\hline $12 / 26 / 1990$ & -50 & -5 & -4 & -5 & -3 & -6 & -5 & -5 & -5 \\
\hline $12 / 27 / 1990$ & 109 & -1 & 0 & 0 & -4 & -3 & -4 & -4 & -5 \\
\hline $1 / 2 / 1991$ & -41 & 3 & 0 & -8 & -10 & -9 & -10 & -11 & -11 \\
\hline $1 / 22 / 1991$ & -31 & 0 & -3 & -2 & -1 & 2 & 2 & 4 & 5 \\
\hline $1 / 23 / 1991$ & 35 & 8 & 1 & 0 & -1 & -3 & -3 & -3 & -2 \\
\hline $1 / 24 / 1991$ & 53 & -1 & -2 & -5 & -4 & -6 & -3 & -4 & -4 \\
\hline $1 / 25 / 1991$ & 46 & 4 & 5 & 7 & 4 & 6 & 5 & 6 & 6 \\
\hline $1 / 28 / 1991$ & 72 & 9 & 3 & 3 & 2 & 0 & 0 & 0 & 0 \\
\hline $12 / 24 / 1991$ & 49 & 4 & 1 & 5 & 1 & 1 & 2 & 0 & 0 \\
\hline $12 / 27 / 1991$ & -46 & 4 & -4 & -1 & -2 & 0 & -1 & -3 & -1 \\
\hline $1 / 2 / 1992$ & -46 & 0 & 1 & 1 & 2 & 5 & 8 & 7 & 6 \\
\hline $11 / 27 / 1992$ & 100 & 2 & 2 & 6 & 13 & 10 & 10 & 9 & 7 \\
\hline $5 / 2 / 1994$ & 41 & 13 & 12 & 5 & 4 & 5 & 5 & 3 & 1 \\
\hline $11 / 25 / 1994$ & 54 & 1 & 1 & 1 & 1 & 1 & 0 & -1 & -2 \\
\hline $12 / 27 / 1994$ & -31 & 6 & 4 & -2 & -6 & -8 & -9 & -9 & -9 \\
\hline $4 / 27 / 1999$ & 70 & 3 & 3 & 2 & -5 & -2 & -2 & -1 & -2 \\
\hline $5 / 13 / 1999$ & -31 & -1 & -1 & -4 & -8 & -10 & -12 & -10 & -9 \\
\hline $5 / 14 / 1999$ & 36 & 5 & 5 & 11 & 19 & 19 & 23 & 21 & 16 \\
\hline $12 / 27 / 1989$ & 47 & -3 & -4 & -1 & 1 & -1 & -3 & -1 & -2 \\
\hline $12 / 28 / 1989$ & 41 & -5 & -4 & -5 & -4 & -4 & -3 & -3 & -2 \\
\hline
\end{tabular}




\begin{tabular}{|l|}
\hline Appendix C: Headline News Events \\
\hline Unemployment rate \\
\hline Housing starts \\
\hline Industrial production \\
\hline Index of leading economic indicators \\
\hline GDP first announced \\
\hline Producer price index \\
\hline Retail sales \\
\hline Consumer price index \\
\hline Advanced durable goods orders \\
\hline Personal income \\
\hline Trade balance \\
\hline
\end{tabular}

\begin{tabular}{|c|c|c|c|c|c|c|c|c|c|}
\hline \multicolumn{10}{|c|}{$\begin{array}{l}\text { Appendix D: Kuttner Shocks and Changes in Treasury Rates on Days When There Are } \\
\text { Unusually Large Kuttner Shocks and No Target Change (basis points), February 3, } 2000 \text { - } \\
\text { June 29, } 2007\end{array}$} \\
\hline Date & K-shock & $t b 3$ & $t b 6$ & $t 1$ & $t 3$ & $t 5$ & $t 7$ & $t 10$ & $t 20$ \\
\hline $10 / 24 / 2000$ & 51 & 1 & 1 & 4 & 3 & 4 & 4 & 4 & 4 \\
\hline $10 / 25 / 2000$ & -52 & 4 & 2 & 4 & 3 & 4 & 5 & 4 & 4 \\
\hline $4 / 2 / 2001$ & -42 & -8 & 7 & 1 & 4 & 4 & 6 & 5 & 4 \\
\hline $9 / 13 / 2001$ & -21 & -52 & -48 & -50 & -50 & -38 & -28 & -20 & -9 \\
\hline 9/18/2001 & -45 & -11 & -6 & -3 & 1 & 2 & 8 & 9 & 15 \\
\hline 9/19/2001 & -57 & -29 & -23 & -20 & -13 & -11 & -5 & -3 & 0 \\
\hline 9/20/2001 & 39 & 3 & 5 & 7 & 9 & 7 & 6 & 6 & 8 \\
\hline $9 / 21 / 2001$ & 27 & 3 & -4 & -3 & 0 & -3 & -4 & -5 & -5 \\
\hline $9 / 24 / 2001$ & 50 & 13 & 5 & 3 & 3 & 6 & 4 & 3 & -1 \\
\hline $12 / 3 / 2001$ & -28 & 0 & 2 & 2 & -2 & -4 & -4 & -3 & -5 \\
\hline $5 / 2 / 2005$ & 24 & 3 & 2 & 1 & -2 & -2 & -1 & 0 & 0 \\
\hline $4 / 3 / 2006$ & 21 & 4 & 5 & 4 & 2 & 3 & 3 & 2 & 1 \\
\hline $7 / 3 / 2006$ & 27 & 7 & 7 & 5 & 1 & 1 & 1 & 0 & 2 \\
\hline
\end{tabular}

